\title{
A Policy Analysis of the Primary Health Care Delivery Programme in Calabar South Local Government Area
}

\author{
C. C. Ikeji \\ Institution of Public Policy \& Administration University of Calabar.
}

\begin{abstract}
The study investigated primary healthcare delivery programme in Calabar South Local Government Area of Cross River State, Nigeria. Two hypotheses were tested in the study using One-sample T-test. Sample size of 90 primary healthcare facilities users was used for the purpose of the study (30 in each of three primary healthcare facilities in Calabar South). Simple random sampling was used for the purpose of the study. The results showed that the Primary Health Care programme has significantly affected health-care delivery in Calabar South Local Government Area, and that the Primary Health Care programme has significantly altered the perception of the policy target groups over health care practices in Calabar South Local Government Area. Based on the findings of the study, recommendations were made.
\end{abstract}

Key Words: Analysis, Health Care, Delivery, Policy Primary.

\section{Introduction}

The state of healthcare system in Nigeria over the years had been and still remains less than desirable. A worrisome statistic shows that although Nigeria accounts for only 2 percent of the world's total population, she accounts for some 10 percent of the world's infant and maternal mortality (Ogunlela, 2011). Consequently, the Federal Government of Nigeria has made attempts to rehabilitate the health sector through a series of reforms. Deliberate efforts have been made to initiate and sustain health sector reforms over the past years. The reform of the sector is predicated upon the fact that the sector is characterized by poor quality of public sector health services, resulting in poor health outcomes when measured against basic health indicators (ADF, 2002).

The current state of the country's healthcare system can be said to be quite worrisome, judging by the health indicators and statistics that are abysmal as noted earlier. In fact, Nigeria's health indicators have stagnated or even deteriorated in the past decades (Gustafsson-Wright et. al., 2008). A distinct feature of the country's healthcare service delivery and management is its decentralization at the three-tier levels involving the primary, secondary and tertiary institutions, managed by the local, state and national governments, respectively.

Both the public and private sectors are participants in healthcare delivery. Health infrastructure, being a part of a larger health system, includes the health policy, budgetary allocation implementation and monitoring (Adebanjo and Oladeji, 2006). The discussion of the healthcare infrastructure in sub-Saharan Africa and Nigeria in particular, has recognized the existence of different types and practices. Regarding nigeria's situation, the picture offers little to cheer about.

At the time of the country's independence in 1960, the health care system was largely engaged in curative care and modern healthcare was found to be almost exclusively in urban areas. The 1970's and 1980's brought about large changes in health care in Nigeria with a dramatic expansion of the public health system. The setting up of Health Management Boards (HMBs) for both Federal Government and State Government controlled health institutions in the 1970's arose partly from the need to rescue healthcare delivery from the claws of civil service bureaucracy (Ogunbekun, 1991). The National health Policy developed in 1986, promulgated in 1988 and later reviewed in 1996, set up a health system, which defines much of what remained today. It recommended four main strategies for effective primary health care implementation. It was not until August 1987 that the Federal Government launched its Primary Healthcare Plan, which was announced as the cornerstone of health policy. In the early 1990's, a community-level component was established as part of the health strategy, including training of primary healthcare workers. Subsequently, in 2004, the Revised National Health Policy was developed by the Federal Ministry of Health (Ogunlela, 2012).

Primary Health Care (PHC), as defined in Alma Ata declaration of 1978, refers to essential health care based on practical and socially acceptable methods and technology made universally acceptable to individuals and families in the community through their full participation, and at a cost the community can afford. The World Health Organization (WHO) defined Primary Healthcare (PHC) as essential healthcare (Adeyemo, 2005).

Being the first level of contact of the individuals and community, in the national health system, healthcare is brought as close as possible to where they live and work and contributes to a continuing healthcare process (Akinsola, 1993).

The aims and objectives of the primary healthcare as specified by WHO in 1987 are as follows: 
i) To make health services accessible and available to all wherever they live and work; ii) To tackle those health problems causing the highest mortality and morbidity at a cost affordable to the community;

iii) To ensure that whatever technology is used must be within the ability of the community to use effectively and maintain;

iv) To ensure that in implementing health programmes, the community must be fully involved in planning, delivery and evaluation of the services in the spirit of self-reliance.

A major policy analytic concern is knowing how far the policy has fared after over one decade of its introduction at the local government level. Accordingly, some basic questions arise: To what extent has the programme met its goals in Calabar South Local Government Area? What is the perception of users/beneficiaries of the programme? What factors affect the outcome recorded since the introduction of the programme?

\section{Hypotheses}

The following hypotheses tested in this study are hereby stated in null form:

1. The Primary Health Care programme has not significantly affected health-care delivery in Calabar South Local Government Area

2. The Primary Health Care programme has not significantly altered the perception of the policy target groups over health care practices in Calabar South Local Government Area.

\section{Objective of the Study}

1. To ascertain the perception of policy target groups about the programme.

2. To identify factors affecting the outcome recorded since the inception of the programme.

\section{Literature Review}

Gustafsson-Wright and van der Gaag, (2008) reminds us that the essence of the systems' reform is because the systems, prior to the time of reform, were not working properly or were not producing the optimal health condition deserved by the people. A health system can be considered as an organizational framework for the distribution or servicing of the healthcare need of a given community (Asuzu, 2004). It is a fairly complex system of inter-related elements that contribute to the health of people. The challenges facing Nigeria's health sector include poor institutional arrangements, defective functional relationships and management mechanisms. The poor performance of the national health system therefore partly reflects a lack of clarity or consensus about which level of government is responsible for what function. Dimensions of policy concern are highlighted:

Infant and maternal mortality: Nigeria has one of the highest rates of infant and maternal mortality in the developing world and this translates to 10 percent of women dying from complications of pregnancy and childbirth (Ogunlela, 2011). There is no doubt that maternal health is a critical issue in Nigeria's economic and social development. The intervention programmes in child survival in the country to a large extent have not made the expected impact.

Emigration of health professionals: Emigration of health professionals out of the shores of the country is a serious challenge and threat to the health sector. Mass exodus of health professionals to developed countries in search of the "greener pastures" has been going on for quite some time now. This is a form of brain drain. Every attempt to stem the tide has not yielded the desired results.

Inadequate health facilities: according to Yohersor (2004), health facilities are inadequate. This includes health centers, personnel and medical equipment. This inadequacy is worse in rural areas. The state of existing facilities is poor as a result of lack of maintenance.

It is heart-warming to note that certain positive developments have been recorded in the health sector. These have come about as a result of the various efforts made by the tiers of government. Concerted efforts have been made to initiate and sustain a number of health sector reforms in Nigeria over the past few years.

Following these reforms are a series of reviews to determine whether or not the initiatives are having the desired effects.

The National Health Policy and Strategy is to achieve health for all Nigerians. It recommends for main strategies for effective primary healthcare implementation. The policy document is a result of several consultative processes, incorporating views from stakeholders and reflecting new realities and trends in the National Health situation including regional and global initiatives such as New Partnership for Africa's Development (NEPAD) and the Millennium Development Goals (MDGs). The National Health Insurance Scheme (NHIS) is a relatively recent development in the nation's health sector, having been established by government about a decade ago. Its coverage is to provide for people gainful employment in the formal sector, either run by government or contracted out to private insurance bodies. 
The Revised National Health Policy Developed by the Federal Ministry of Health clearly sets out the primary health issues for the nation in its overall objective. Global health initiatives such as the MDGs and PHC have been catalysts for great political commitment to health of the citizens of the country. Primary health care is the cornerstone for healthcare system and development in Nigeria (Ogunlela, 2011). Hence, a working document has been developed for the revitalization of the implementation of primary health care as part of government stewardship role to reach the Millennium Development Goals. PHC, as defined in Alma Ata declaration of 1978 , refers to essential health care based on practical and socially acceptable methods and technology made universally acceptable to individuals and families in the community through their full participation, and at a cost the community can afford (Ebuenyi, 2009).

The principle upon which the PHC is funded is that health is a fundamental human right to be enjoyed by the people, in all walks of life, in all communities. Health care, based on primary healthcare include things such as: education concerning prevailing health problems and methods of preventing and controlling them; promotion of food supply and proper nutrition; maternal and child care, including family planning; immunization against the major infectious diseases; prevention and control of locally endemic and epidemic diseases and provision of essential drugs and supplies (FMH, 2009). Therefore, public healthcare is to provide general health services to the population as entry point of the healthcare system. It implies that the provision of health care at this level is largely the responsibility of local governments.

The National Health Policy, developed in 1986, was promulgated in 1988 and reviewed in 1996. It recommended four main strategies for effective primary health care implementation (Inem, 2005). The main policy thrust focuses on National Health System and its Management, Management Health Care Resources, National Health Interventions and Services delivery, National Health Information Systems, Partnership for Health Development, Health Research and Health Care Laws. The policy document is a result of several consultative processes, incorporating views from stakeholders and reflecting new realities and trends in the national health situation, including regional and global initiatives such as NEPAD and the MDGs. The Revised National Health Policy, which was developed in 2004, clearly states the priority health issues for the nation in its overall objective. The overall objective is to strengthen the national health system such that it would be able to provide effective, efficient, quality, accessible and affordable health services that will improve the health status of Nigerians through the achievement of the health related MDGs (FMH, 2004). The health policy has a pivotal goal, which is, to bring about a comprehensive healthcare system based on primary healthcare that is promotive, preventive, protective, restorative and rehabilitative to every Nigerian within the available resources towards ensuring the productivity and social wellbeing of all. Hence, the overall goal of the policy is the attainment of enhanced standards of health by all Nigerians in order to promote a healthy and productive life.

The guiding principles of the policy, among others, include emphasis on primary healthcare and introduction of basic health services scheme, mainstreaming of gender issues in planning and implementation and a special focus on health systems development (Asuzu, 2004). The country's National Health Policy affirms the centrality of health to social and economic development.

According to Ogunlela (2011), fundamental reforms of the health sector have been embarked upon with a view to attaining the MDGs and other national health policy targets. The hope is that these would result more effective, affordable and efficient health services, improved performance of the healthcare system and ultimately in the achievement of a better health status for the citizenry.

\section{Theoretical Framework}

One particularly useful framework, which has structured inquiry across a broad array of policy sectors and disciplines, is the Institutional Analysis Development (IAD) framework. Developed by Elinor Ostrom and other scholars associated with the Workshop in Political Theory and Policy Analysis at Indiana University, the IAD framework focuses the analyst's attention on individuals who make decisions over some course of action.

Policy processes and outcomes are assumed to be affected, to some degree, by four types of variables external to individuals: (1) attributes of the physical world, (2) attributes of the community within which actors are embedded, (3) rules that create incentives and constraints for certain actions, and (4) interactions with other individuals (see Ostrom, et al. 1994).

It starts with the action arena as the unit of analysis and focus of investigation. An action situation is the "social space where individuals interact, exchange goods and services, engage in appropriation and provision activities, solve problems, or fight". It includes the following elements: "participants in positions who must decide among diverse actions in light of the information they possess about how actions are linked to the potential outcomes and the costs and benefits assigned to actions and outcomes". An actor is the individual, or group functioning as a corporate actor, who takes action.

In the light of this study, attributes of the physical world, and of the community within which actors are embedded is the need to know how far the Primary Healthcare Delivery policy has fared after over a decade of its introduction at the local government level. The rules that create incentives and contraints for certain actions 
are the National Health Policy by the Federal Government (and adopted by the states, including Cross River State). And the interactions with other individuals are the interaction and relationship between health personnel and users of the primary healthcare facilities, and the community at large.

\section{Research Methodology}

\section{Study Area}

Calabar South Local Government Area of Cross River State, Nigeria is chosen as the focus of this study. The indigenes of Calabar South are people of the Efik tribe. The traditional occupation of the people includes fishing, farming, trading, artisanship, etc.

\section{Sample Size}

Sample size of 90 is used for the purpose of this study. In other words, 90 users of primary healthcare facilities in Calabar South are used as respondents to questionnaire administered for the purpose of the study. The 90 respondents are evenly spread around the three primary healthcare centres situated in the local government (i.e. 30 in each centre).

\section{Sampling Technique}

Simple Random Sampling is used for the purpose of this study. Simple random sampling is used so as to give every user of primary healthcare facilities equal chances of being selected for the purpose of data collection. Simple random sampling is used so as to eliminate bias or reduce it to the barest minimum, such that the observations are representative of the population.

\section{Data Collection Procedure}

Data collection is done by the use of well-structured questionnaire. A structured questionnaire was administered to 90 users of the 3 primary healthcare facilities in Calabar South (i.e. 30 users in each center). Their responses are used as data for the purpose of this study.

\section{Analytical Procedure}

One-sample T-test was used for the purpose of this study. One-sample T-test was used to test each of the two research hypotheses. One-sample T-test was used because it is a statistical tool for making deductive inference based on observation of data.

\section{Results}

\section{Results and Discussion}

Table 1 below shows the descriptive statistics of observation on the variable Healthcare Delivery. Mean is 3.59 indicating that most of the respondents tend toward Strongly Agreeing with the notion that the Primary Health Care programme has significantly affected health-care delivery in Calabar South Local Government Area

Table 1: Descriptive Statistics for Healthcare Delivery

\begin{tabular}{|l|l|l|l|l|}
\hline & $\mathrm{N}$ & Mean & Std. Deviation & Std. Error Mean \\
\hline $\begin{array}{l}\text { Healthcare } \\
\text { Delivery }\end{array}$ & 120 & 3.5875 & .42610 & .03890 \\
\hline
\end{tabular}

\section{Test of Hypothesis One:}

Table 2 below shows result for the test of Hypothesis One.

$\mathrm{H}_{0}$ : The Primary Health Care programme has not significantly affected health-care delivery in Calabar South Local Government Area

$\mathrm{H}_{\mathrm{a}}$ : The Primary Health Care programme has significantly affected health-care delivery in Calabar South Local Government Area

$H_{0}$ : Mean $=2.00$ vs. $H_{a}:$ Mean $>2.00$ 
Table 2: One-Sample T-Test for Healthcare Delivery

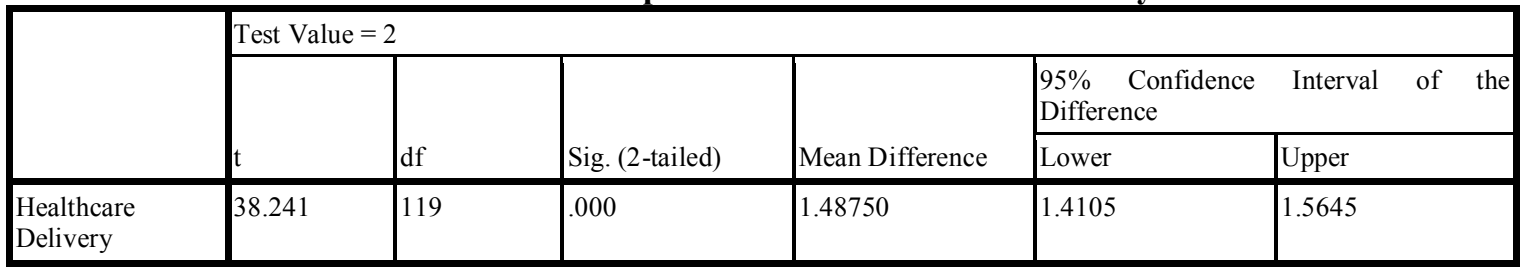

Statistical tool: One-sample t-test.

Decision Rule: When Test Statistic $T$ is greater than tabulated statistic $t$, reject $\mathrm{H}_{0}$ and accept $\mathrm{H}_{\mathrm{a}}$, but when Test Statistic $\mathrm{T}$ is less than tabulated statistic $\mathrm{t}$, accept $\mathrm{H}_{0}$ and reject $\mathrm{H}_{\mathrm{a}}$

Test Statistic $\mathrm{T}=\mathrm{X}-\mu /(\mathrm{s} / \sqrt{ } \mathrm{n})$

Where $\mathrm{X}=$ observed mean

$\mu=$ population mean

$\mathrm{s}=$ standard deviation

$\mathrm{n}=$ number of observations

$=3.59-2 /(0.43 / 10.95)$

$=40.77$

Decision: Since the Test Statistic T (40.77) is greater than the tabulated statistic (38.24), we therefore do have enough statistical evidence to reject $\mathrm{H}_{0}$ and accept $\mathrm{H}_{\mathrm{a}}$, we therefore accept $\mathrm{H}_{\mathrm{a}}$ and conclude that: The Primary Health Care programme has significantly affected health-care delivery in Calabar South Local Government Area.

Table 3 below shows the descriptive statistics of observation of variable Impact. The Mean is 3.48 indicating that most of the respondents tend toward Strongly Agreeing with the notion that primary health care facilities have a positive impact on the well-being of the communities and the people of Calabar South Local Government Area.

Table 3: Descriptive Statistics for Impact

\begin{tabular}{|l|l|l|l|l|}
\hline & $\mathrm{N}$ & Mean & Std. Deviation & Std. Error Mean \\
\hline Perception of policy target groups & 120 & 3.4833 & .42842 & .03911 \\
\hline
\end{tabular}

\section{Test of Hypothesis Two:}

Table 4 below shows result for the test of Hypothesis Two.

$\mathrm{H}_{0}$ : The Primary Health Care programme has not significantly altered the perception of the policy target groups over health care practices in Calabar South Local Government Area.

$\mathrm{H}_{\mathrm{a}}$ : The Primary Health Care programme has significantly altered the perception of the policy target groups over health care practices in Calabar South Local Government Area

$H_{0}$ : Mean $=2.00$ vs. $H_{a}$ : Mean $>2.00$

Table 4: One-Sample T-Test for Impact

\begin{tabular}{|c|c|c|c|c|c|c|}
\hline & \multicolumn{6}{|c|}{ Test Value $=2$} \\
\hline & \multirow[b]{2}{*}{$t$} & \multirow[b]{2}{*}{$\mathrm{df}$} & \multirow[b]{2}{*}{ Sig. (2-tailed) } & \multirow{2}{*}{$\begin{array}{l}\text { Mean } \\
\text { Difference }\end{array}$} & \multicolumn{2}{|c|}{$\begin{array}{l}\text { 95\% Confidence Interval of the } \\
\text { Difference }\end{array}$} \\
\hline & & & & & Lower & Upper \\
\hline Perception & 37.928 & 119 & .000 & 1.48333 & 1.4059 & 1.5608 \\
\hline
\end{tabular}

Statistical tool: One-sample t-test.

Decision Rule: When Test Statistic $\mathrm{T}$ is greater than tabulated statistic $t$, reject $\mathrm{H}_{0}$ and accept $\mathrm{H}_{\mathrm{a}}$, but when Test Statistic T is less than tabulated statistic $t$, accept $\mathrm{H}_{0}$ and reject $\mathrm{H}_{\mathrm{a}}$

Test Statistic $\mathrm{T}=\mathrm{X}-\mu /(\mathrm{s} / \sqrt{ } \mathrm{n})$

Where $\mathrm{X}=$ observed mean

$\mu=$ population mean

$\mathrm{s}=$ standard deviation

$\mathrm{n}=$ number of observations

$=3.48-2 /(0.43 / 10.95)$ 
$=37.95$

Decision: Since the Test Statistic T (37.95) is greater than the tabulated statistic (38.24), we therefore do have enough statistical evidence to reject $\mathrm{H}_{0}$ and accept $\mathrm{H}_{\mathrm{a}}$, we therefore accept $\mathrm{H}_{\mathrm{a}}$ and conclude that: The Primary Health Care programme has significantly altered the perception of the policy target groups over health care practices in Calabar South Local Government Area.

Table 5: Factors Affecting the Outcome Recorded since the Democratic Dispensation

\begin{tabular}{|l|l|l|}
\hline Factors State Government & Number of Agreeing Respondents & Percentage (\%) \\
\hline $\begin{array}{l}\text { Direct } \\
\text { Involvement }\end{array}$ & 115 & 96 \\
\hline Better Funding & 103 & 86 \\
\hline $\begin{array}{l}\text { Better Welfare Package for Health } \\
\text { Personnel }\end{array}$ & 106 & 88 \\
\hline More Participation of Target Group & 65 & 54 \\
\hline
\end{tabular}

From Table 5 above shows the factors affecting the recorded outcome as perceived by stakeholders in the primary healthcare delivery sector in Calabar South Local Government. These stakeholders include health personnel, users of the primary healthcare facilities (members of the community) and health researchers. It is shown that $115(96 \%)$ respondents considered Direct state government involvement as a positive factor affecting the recorded outcome, $103(86 \%)$ respondents considered Better Funding as a positive factor affecting the recorded outcome, $106(88 \%)$ considered Better Welfare Package for Health Personnel as positive factor affecting the recorded outcome, while $65(54 \%)$ considered More Participation of Target Group as positive factor affecting the recorded outcome.

\section{Discussion}

According to Bernan (1995), health sector reforms has been described as sustainable, purposeful change aimed at improving the existing health sector, the findings of this research shows that the reforms introduced in the Nigerian health sector since the inception of the democratic dispensation is paying off. This is shown and supported by results of the two hypotheses tested in the course of this study. Hypothesis one showed the result that the residents (users of primary healthcare facilities) of Calabar South of primary healthcare facilities in Calabar South consider the primary healthcare facilities there as having significantly affected healthcare delivery (positively). Hypothesis Two showed that residents (users of primary healthcare facilities) of Calabar South of primary healthcare facilities in Calabar South consider the primary healthcare facilities there as having altered the perception of the policy target groups over healthcare practices in the local government area.

These findings are in consonance with the findings of Ogunlela (2011) titled "An appraisal of Nigeria's health sector and its healthcare delivery system", he stated that The Nigerian health sector has no doubt recorded some remarkable achievements in recent years. Recent developments point to the fact that the sector is on the right track while the series of reforms will move the sector to the next level. He further stated that deliberate efforts have been made by the Federal Government of Nigeria to initiate and sustain health sector reforms over the past many years. The reform of the sector is predicated upon the fact that it is characterized by poor quality and inefficiencies in the provision of public sector health services, resulting in poor health outcomes and poor basic health indicators. This view is also supported by an African Development Fund (2002) paper titled "Appraisal Report of Health Systems Development Project". The findings of this study show that some of the desired results from the Health reforms are bearing fruit.

Ogunlela (2011) in his study further stated that it is heart-warming to note that certain positive developments have been recorded in the health sector. These have come about as a result of the various efforts made by the tiers of government. Concerted efforts have been made to initiate and sustain a number of health sector reforms in Nigeria over the past many years. Following these reforms are a series of reviews to determine whether or not the initiatives are having the desired effects. The National Health Policy and Strategy is to achieve health for all Nigerians. It recommends for main strategies for effective primary healthcare implementation. The policy document is a result of several consultative processes, incorporating views from stakeholders and reflecting new realities and trends in the National Health situation including regional and global initiatives such as New Partnership for Africas Development (NEPAD) and the Millennium Development Goals (MDGs). His postulations are in consonance with the findings of this study.

According to Ebuenyi (2009), Adeyemo (1995), Akinsola (1993) and Ogunlela (2011), Primary health care is the cornerstone for healthcare system and development in Nigeria. Being the first level of contact of the individuals and community, in the national health system, healthcare is brought as close as possible to where they live and work and contributes to a continuing healthcare process. These views are supported by the findings of this study. It is however worthy of note that the primary healthcare centers in Calabar South are under the funding and supervision of the state government ministry of health, and not under the local government council. 
Therefore much credit should accrue to the state government for the progress and success achieved in the primary health sector, as shown by the findings of this study.

\section{Conclusion}

The findings of this study show that there has been a marked improvement in health sector of Nigeria over the last few years as envisaged in the National Health Policy, as shown by primary healthcare service delivery in Calabar South Local Government Area of Cross River State. Much credit should go to the state government for the progress made over the years. From the findings of this study the residents of Calabar South both consider the primary healthcare facilities as having significantly affected healthcare delivery, and having significantly altered the perception (positively) of the policy target groups. However much still has to be done to sustain this level of success, and even reach for greater successes. Therefore the government (at all levels) and all stakeholders in the health sector should not rest on their oars (Ebuenyi, 2009; Adeyemo, 1995; Akinsola, 1993; Ogunlela, 2011; Yohersor, 2004; NAFDAC, 2004; FMH, 2009).

\section{Recommendation}

The following recommendations are made to the government and all stakeholders e.g. health personnel, communities, private sector, etc:

1. There is need for clarity or consensus about which level of government is responsible for what function since the three tiers of government participate in the health sector resulting in serious overlaps. In fact, the local government tier should play a more active role in providing and ensuring the availability of primary healthcare delivery at the grassroots level.

2. There should be a collaborative approach to service delivery and a system of ensuring the private sector is fully engaged in service provision.

3. Greater attention should be given to health research. There should be better appreciation of health research and a culture of utilizing generated data to take informed actions, make good decisions or for sound policy formulation.

4. Special attention should be given to the provision of the healthcare service to rural areas, which have hitherto been neglected. The present lopsided distribution of health facilities in favour of the urban areas should be strictly avoided. That is, there should be equity in the distribution of healthcare facilities and infrastructure.

5. Other non-orthodox forms of healthcare delivery should not be ignored but rather be promoted and enhanced to provide traditional healing. Research and development in this area must be encouraged.

\section{References}

[1]. Adebanjo, A. A. and Oladeji, S. I. 2006. Health capital condition: Analysis of the determinants in Nigeria. In Falola, T. and Heaton, M. M. (eds). Traditional and Modern Health Systems in Nigeria. Africa World Press, Trenton and Asmara, pp. 381-398.

[2]. Adeyemo, D. O. 2005. Local government and health care delivery in Nigeria: A case study. J. Hum. Ecol. 18(2):149-160.

[3]. African Development Fund 2002. Appraisal Report of Health Systems Development Project. African Development Fund, Abidjan, Ivory Coast, 51p.

[4]. Akinsola, H. A. 1993. Community Health and Social Medicine in Medical and Nursing Practice. 3 AM Communications, Ibadan, Nigeria.

[5]. Asuzu, M. C. 2004. The necessity for a health systems reform in Nigeria. J. Comm. Med. Prim. Health Care 16(1):1-3.

[6]. Ebuenyi, I. D. 2009. The bane of the health care system in Nigeria. Taking IT Global.org, March 4, 2011.

[7]. Federal Ministry of Health 2004. Revised National Health Policy. Federal Ministry of Health, Abuja, Nigeria.

[8]. Federal Ministry of Health 2009. National Health Policy. Federal Ministry of Health, Abuja, Nigeria.

[9]. Gustafsson-Wright, E. and van der Gaag, J. 2008. An Analysis of Nigeria's Health Sector by State: Recommendations for the Expansion of the Hygeia Community Health Plan. Amsterdam Institute for International Development, $35 \mathrm{p}$

[10]. Inem, V. 2005. Financing of Primary Health Care System in Nigeria. Lagos University Teaching Hospital and College of Medicine, University of Lagos, Nigeria.

[11]. Ogunbekun, I. O. 1991. Which direction for health care in Nigeria? Health Policy and Planning 6(3):254-261.

[12]. Ogunlela Y. I. (2011). An appraisal of Nigeria's health sector and its healthcare delivery system. Journal of Food, Agriculture \& Environment Vol.9 (3\&4): 81-84. 2011

[13]. Ostrom, Elinor. 1990. Governing the Commons: The Evolution of Institutions for Collective Action. Cambridge: Cambridge University Press.

[14]. Yohersor, A. 2004. Social Health Insurance that Works: Recommendation to National Health Insurance Scheme.Vast Publications, Abuja.

[15]. Berman, P. (1995). Health sector reform: Making health development sustainable. Health Policy 32:13-28

[16]. Omoruan, A. I., Bandele, A. P. and Phillips, O. P. (2009). Social health insurance and sustainable healthcare reform in Nigeria. Ethno-Med. 3(2): $105-110$.

[17]. Akinwumi, F. 2010. Nigeria: Challenges facing Nigerian health system. Daily Independent, 5 May 2010, Lagos, Nigeria

[18]. Adebanjo, A. A. and Oladeji, S. I. 2006. Health capital condition: Analysis of the determinants in Nigeria. In Falola, T. and Heaton, M. M. (eds). Traditional and Modern Health Systems in Nigeria. Africa World Press, Trenton and Asmara, pp. 381-398.

[19]. Owumi, B. 2005. African Values, Beliefs and Polemics of Developing Traditional Medicine in Contemporary Times. Faculty of Social Sciences, University of Ibadan, Lecture Series No. 13.

[20]. Erinosho, O. A. 2006. Health Sociology for Universities, Colleges and Health Related Institutions. Bulwark Consult, Abuja, Nigeria. 


\section{Appendix}

A Policy Analysis of the Primary Health Care Delivery Programme In Calabar South Local Government Area

\section{Dear Sir/Madam}

This questionnaire is issued for the purpose of obtaining response (data) for research on the above topic. The researcher hereby solicits your honest response. All responses (including yours) are treated with utmost anonymity. The respondent therefore is at no risk(s) in giving honest response to all (any) items on the questionnaire.

Thanks for your cooperation.

Yours

Chibueze Ikeji Ph.D

\section{Questionnaire}

\section{Section A}

\section{Socioeconomic Characteristics}

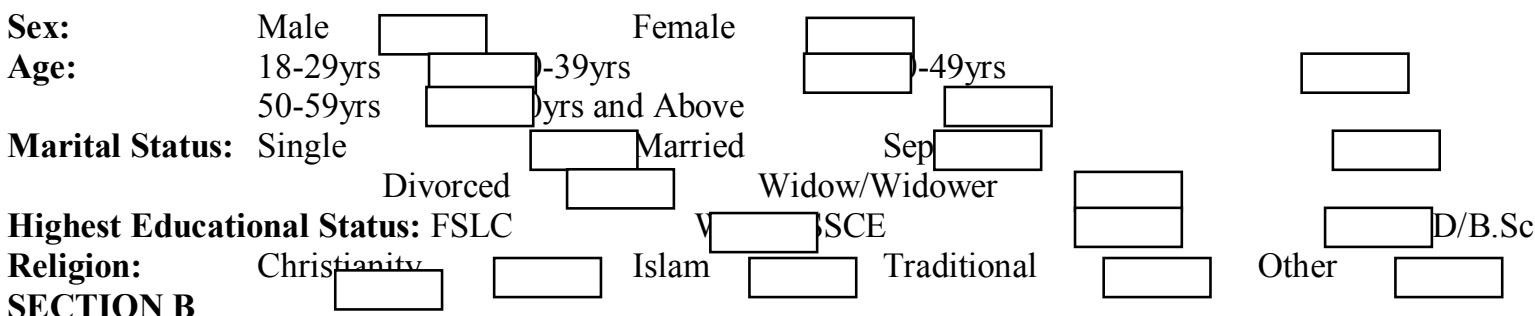

\section{SECTION B}

Data On Research Variables

Below is a list of items, for each, tick as appropriate.

\begin{tabular}{|c|c|c|c|c|c|}
\hline $\mathbf{S} / \mathbf{N}$ & A. Healthcare Delivery & $\begin{array}{l}\text { Strongly } \\
\text { agree (SA) }\end{array}$ & Agree (A) & Disagree (D) & $\begin{array}{l}\text { Strongly } \\
\text { disagree (SD) }\end{array}$ \\
\hline 1 & $\begin{array}{l}\text { The Centre is usually open to attend } \\
\text { to health issues }\end{array}$ & & & & \\
\hline 2 & $\begin{array}{l}\text { The Centre is adequately staffed } \\
\text { with qualified personnel }\end{array}$ & & & & \\
\hline 3 & $\begin{array}{l}\text { The Centre is adequately equipped } \\
\text { with modern equipment and } \\
\text { materials }\end{array}$ & & & & \\
\hline 4 & $\begin{array}{l}\text { The Centre attends to all issues } \\
\text { without discrimination }\end{array}$ & & & & \\
\hline 5 & $\begin{array}{l}\text { The Centre helps in cure of } \\
\text { illnesses/diseases }\end{array}$ & & & & \\
\hline 6 & $\begin{array}{l}\text { The Centre has helped in preserving } \\
\text { lives of residents }\end{array}$ & & & & \\
\hline 7 & $\begin{array}{l}\text { The center has contributed to } \\
\text { productiveness of residents by } \\
\text { helping them stay healthy }\end{array}$ & & & & \\
\hline \multicolumn{2}{|c|}{ B. Perception of policy target groups } & $\begin{array}{l}\text { Strongly } \\
\text { agree (SA) }\end{array}$ & Agree (A) & Disagree (D) & $\begin{array}{l}\text { Strongly } \\
\text { disagree (SD) }\end{array}$ \\
\hline 8 & $\begin{array}{l}\text { The center gives good health } \\
\text { education to residents }\end{array}$ & & & & \\
\hline 9 & $\begin{array}{l}\text { The Centre has changed people's } \\
\text { attitude towards beliefs as to } \\
\text { sources of diseases }\end{array}$ & & & & \\
\hline 10 & $\begin{array}{l}\text { The coming of the Centre has } \\
\text { reduced dependence on traditional } \\
\text { medicare alternatives }\end{array}$ & & & & \\
\hline 11 & $\begin{array}{l}\text { The Coming of the Centre has } \\
\text { increased people's faith in public } \\
\text { healthcare delivery system }\end{array}$ & & & & \\
\hline \multicolumn{2}{|c|}{ Possible Factors Affecting Outcome } & \multicolumn{2}{|l|}{ Agree } & \multicolumn{2}{|l|}{ Disagree } \\
\hline 1 & $\begin{array}{l}\text { Direct State Government } \\
\text { Involvement }\end{array}$ & & & & \\
\hline 2 & Better Funding & & & & \\
\hline 3 & $\begin{array}{l}\text { Better Welfare Package for Health } \\
\text { Personnel }\end{array}$ & & & & \\
\hline 4 & More Participation of Target Group & & & & \\
\hline
\end{tabular}

